\title{
Screening of sub-clinical mastitis in dairy cows of organised farms using three diagnostic tests
}

\author{
M. G. Amritha Priya ${ }^{1}$, K. Vijayakumar ${ }^{2}$ K. Vinodkumar ${ }^{3}$,
}

K. Justin Davis ${ }^{3}$, G. Radhika ${ }^{4}$

Department of Veterinary Epidemiology and Preventive Medicine, College of Veterinary and Animal Sciences, Mannuthy, Thrissur-680651. Kerala Veterinary and Animal Sciences University, Pookode, Wayanad

Citation: Amritha Priya, M. G, Vijayakumar, K., Vinodkumar, K., Justin Davis, K., and Radhika, G. 2021. Screening of sub-clinical mastitis in dairy cows of organised farms using three diagnostic tests. J. Vet. Anim. Sci. 52(1): 73-76. DOI: https://doi.org/10.51966/jvas.2021.52.1.73-76

Received : 11.08.2019

Accepted: 08.11.2019

Published: 01.01.2021

\begin{abstract}
The present study was envisaged for the detection of subclinical mastitis in 108 apparently healthy dairy cows of University Livestock Farm, Mannuthy and Livestock Research Station, Thiruvazhamkunnu. The quarter milk samples collected under sterile conditions were screened using California mastitis test, somatic cell counting and electrical conductivity. A high prevalence of 54 per cent was recorded in the present study. The results indicated the importance of maintaining proper hygienic practices inside farm and good udder health management to enhance quality milk production.
\end{abstract}

Keywords: Subclinical mastitis, Screening tests, Prevalence study, Thrissur district.

Subclinical mastitis (SCM) is the inflammation of the mammary gland that does not create any visible changes in the milk or of the udder (Langer et al. 2014). Even though the milk appears normal, SCM can result in 10-20 per cent loss in total yield and causes deterioration in quality and nutritional value of milk produced. Hence, early detection of subclinical mastitis for proper management is of great importance to reduce its undesirable effects. Absence of any visible abnormalities in milk demands the requirement of special diagnostic aids for early detection of SCM. Several cow side tests such as California Mastitis Test (CMT), modified white side test (MWT), bromothymol blue card test, determination of electrical conductivity, chloride estimation test, modified Aulendorfer mastitis probe test (MAMP), inline monitoring of SCC and infrared thermography have been used for SCM screening at field level (Kamphuis et al., 2008). Laboratory tests used for screening include $\mathrm{N}$-acetyl- $\beta$-D-glucosaminidase (NAGase), enzyme-linked immunosorbent assay

${ }^{*}$ Forms part of the MVSc thesis submitted by the first author to the Kerala Veterinary and Animal Sciences University, Pookode, Wayanad, Kerala.

1. MVSc. Scholar; emaillD : amritha.priya44@gmail.com

2. Professor and Head

3. Assistant Professor

4. Assistant Professor, Centre for Advanced Studies in Animal Genetics and Breeding

Copyright: (C) 2021 Amritha Priya et al. This is an open access article distributed under the terms of the Creative Commons Attribution 4.0 International License (http://creativecommons.org/licenses/by/4.0/), which permits unrestricted use, distribution, and reproduction in any medium, provided the original author and source are credited. 
(ELISA) (Polat et al., 2010) and acute phase protein determination in milk and in serum (More, 2009). The microbiological status of the quarter and the somatic cell count (SCC) are the most common tests to detect changes in the milk because of an inflammatory process.

\section{Materials and methods}

The study was conducted apparently healthy dairy cows of University Livestock Farm, Mannuthy and Livestock Research Station, Thiruvizhamkunnu during the period October 2017 to January 2018.

A total of 420 quarter milk samples from 108 apparently healthy cows were aseptically collected for screening of SCM using CMT, SCC and EC score. Twelve quarters were found to lack any kind of secretions. About $5 \mathrm{~mL}$ of the milk was collected into a sterile sample collection vial after discarding initial squirts of milk for bacterial isolation.

When all the three diagnostic tests are considered together, the animals having minimum of two quarter CMT grade above 2, SCC value above 200000 cells $/ \mathrm{ml}$ and EC score below 300 were considered positive for SCM. The criteria to classify the affected and healthy quarters were followed as described by Raj (2017).

\section{California mastitis test (CMT)}

The CMT was performed using reagents obtained from Nice Chemicals Pvt. Ltd. Kochi, Kerala. A plastic paddle with four chambers was used to perform the test. Milk from each quarter was drawn to separate chambers. An equal quantity of milk was mixed with the mastitis reagent and mixed well. The paddle was shaken gently in a rotating manner in a horizontal plane and the reaction was scored within $15 \mathrm{sec}$.

Table 1. Interpretation of CMT results

\begin{tabular}{|c|c|c|}
\hline SI. No. & CMT score & Interpretation \\
\hline 1 & 0 & No reaction or trace \\
\hline 2 & 1 & Weak positive \\
\hline 3 & 2 & Moderate positive \\
\hline 4 & 3 & Strong positive \\
\hline
\end{tabular}

The samples with CMT scores above two for minimum two quarters were considered positive for SCM

\section{Somatic cell count (SCC)}

The milk samples were mixed well by shaking the vials and 10 microliters of milk was drawn using a micropipette into the pre-drawn one $\mathrm{cm}^{2}$ marked glass slides. Milk was spread uniformly over the pre-drawn area using a standard sterilized bacteriological platinum loop and the smear was dried at room temperature. The dried smears were stained by Modified Newman's stain by keeping the smear in the staining solution for $5 \mathrm{~min}$. The smears were gently washed in tap water, dried and examined under oil immersion objective of microscope to count cells in ten fields. The average of the cells per field was multiplied by the microscopic factor (4500).

The total number of cells per millilitre of milk was calculated by the formula:

Cell count per millilitre of milk = Average number of cells per field $\times 4500 \times 100$

The quarters with an SCC value of more than 200000 cells $/ \mathrm{ml}$ of milk were considered positive for SCM.

\section{Electrical conductivity score (EC)}

A commercial multi quarter hand held electrical conductivity meter (Draminski, Poland) was used for the detection of EC. The procedure was followed under the manufacturer's instructions. Based on the EC, values were assigned to the samples by the machine. The values below 300 were taken as positive for subclinical mastitis. The quarters with an EC score below 300 were taken as positive for SCM.

\section{Results and Discussion}

The results of three screening tests for detection of SCM are depicted in the Fig (1). Out of 420 quarter samples screened 195 samples were categorised as grade ' 0 ', 62 were grade ' 1 ', 108 samples were grade ' 2 ' and 55 samples were grade ' 3 '. The results indicated that 163 (39 per cent) animals had a CMT score above grade 2 and were considered positive by CMT. 


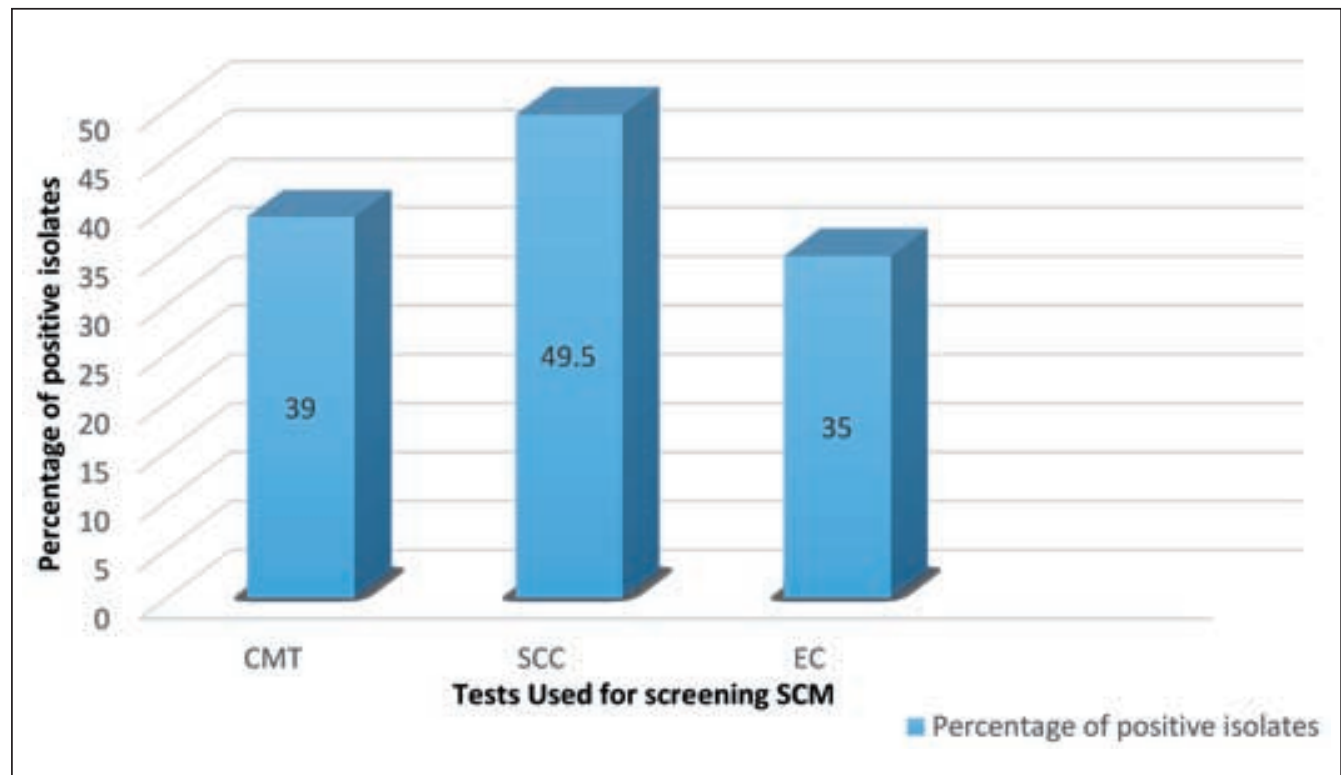

Fig. 1 Results of three diagnostic tests used for screening subclinical mastitis

The results were agreement with the results obtained by Islam et al. (2010) with 37.58 per cent positive cases. The variation in CMT value in different studies may be attributed to the differences in management practices, breed of the animal and geographical locations.

Among 420 samples, 72 samples had SCC score below 100000 cells $/ \mathrm{ml}, 140$ samples had SCC value between 100000 and 200000 cells $/ \mathrm{ml}, 128$ samples had value between 200000 and 500000 cells $/ \mathrm{ml}$ and 80 samples had SCC value above 500000 cells $/ \mathrm{ml}$ of milk. Out of total quarters tested, 49.5 per cent of quarters had an SCC value above 200000 cells $/ \mathrm{ml}$ and were considered positive by SCC value. A much higher prevalence of 71.9 per cent positive cases of SCM was observed in a study conducted in Bangladesh by Hoque et al (2015). Apart from IMI, SCC of bovine milk can show variations depending upon the lactation period of cow, age, breed, stress level and management practices adopted (Sargeant et al., 2001 and Pyorala, 2003).

The EC values interpreted using Draminski EC meter grouped 273 quarter samples as $>300$ score, 107 samples between 250 and 300 and 40 samples below 250 .
Out of total quarters tested, 35 per cent of quarters had an EC value below 300 and were considered positive by EC value. The results were contradictory to that obtained by Langer et al. (2014) and Raj et al. (2017) which were 11.3 per cent and 14 per cent respectively. Many other factors can contribute to variations in conductivity of milk such as temperature, diseases other than mastitis, breed, environmental conditions, milk fat and stage of lactation (Panchal et al., 2016).

The study indicated variations in test results for the same animal in detection of true positive animals having SCM infections when a single test is used. A combination of two or more tests should be hence employed for accurate screening of SCM. In the present study, from among 108 cows, 58 animals (54 per cent) which had at least two quarters CMT grade above 2, EC value below 300 and SCC value above 200000 cells $/ \mathrm{ml}$ were considered positive for SCM. The results were similar to the findings obtained by Sharma et al. (2010) who got an overall prevalence of SCM at cow level as 54 per cent. Even though, pathogen identification by culture technique is considered as gold standard diagnostic test, the time and labour consumption makes it less applicable for field level diagnosis. 


\section{References}

Hoque, M.N., Das, Z.C., Talukder, A.K., Alam, M.S. and Rahman, A.N.M.A. 2015. Differentscreeningtestsand milksomatic cell count for the prevalence of subclinical bovine mastitis in Bangladesh. Trop. Anim. Hlth. prod. 47:79-86.

Islam, M.A., Rahman, A.K.M.A., Rony, S.A. and Islam, M.S. 2010. Prevalence and risk factors of mastitis in lactating dairy cows at Baghabari milk shed area of Sirajganj. Bangladesh J. Vet.Med.8:157162.

Kamphuis, C., Sherlock, R., Jago, J., Mein, G. and Hogeveen, H. 2008. Automatic detection of clinical mastitis is improved by in-line monitoring of somatic cell count. J. Dairy Sci. 91:4560-4570.

Langer, A., Sharma, S., Sharma, N.K. and Nauriyal, D.S.2014.Comparative efficacy of different mastitis markers for diagnosis of sub-clinical mastitis in cows. Int.J. Appl. Sci. Biotechnol. 2:121-125.

More, S.J., 2009. Global trends in milk quality: implications for the Irish dairy industry. Irish Vet. J. 62:S4-S5.

Panchal, I., Sawhney, I.K. and Dang, A.K.2016. Relation between electrical conductivity, dielectric constant, somatic cell count and some other milk quality parameters in diagnosis of subclinical mastitis in Murrah buffaloes. Indian J.Dairy Sci. 69:453-462
Polat, B., Colak, A., Cengiz, M., Yanmaz, L.E., Oral, H., Bastan, A., Kaya, S. and Hayirli, A. 2010. Sensitivity and specificity of infrared thermography in detection of subclinical mastitis in dairy cows. J. Dairy Sci. 93:3525-3532.

Pyorala, S. 2003. Indicators of inflammation in the diagnosis of mastitis. Vet. Res. 34:565-578.

Sargeant, J.M., Leslie, K.E., Shirley, J.E., Pulkrabek, B.J. and Lim, G.H. 2001. Sensitivity and specificity of somatic cell count and California Mastitis Test for identifying intramammary infection in early lactation. J. Dairy Sci.84:20182024.

Raj, 2017. Acute phase proteins in serum and milk as diagnostic tools in bovine subclinical mastitis. M.V.Sc thesis, Kerala Veterinary and Animal Sciences University, Pookode, 91p.

Sharma, N., Pandey, V. and Sudhan, N.A. 2010. Comparison of some indirect screening tests for detection of subclinical mastitis in dairy cows. Bulgarian J. Vet. Med. 13:43-54

Smith, K.L., 1999. Suggested interpretation of mastitis terminology. Bull.Int.Dairy Fed. 338:3-26. 